\title{
Human major HSP70 protein complements the localization and functional defects of cytoplasmic mutant SV40 $T$ antigen in Swiss 3T3 mouse fibroblast cells
}

\author{
Doo-Il Jeoung, Suzie Chen, Jimmy Windsor, and Robert E. Pollack \\ Department of Biological Sciences, Columbia University, New York, New York 10027 USA
}

The CT3 cytoplasmic localization mutant of SV40 T antigen is neither properly transported to the nucleus nor is it functional in rodent cells. Human precrisis cells are able to complement this mutation, as they are fully transformed by CT3 with wild-type efficiency. The human-specific factors responsible for this species-specific difference in response to CT3 were localized to human chromosome 6 by synteny in a panel of six somatic cell hybrids. A major human HSP70 heat shock protein located on chromosome 6 is expressed constitutively in human cells. Hsp70 proteins have been reported to play a role in intracellular movement of newly synthesized proteins. To test whether human HSP70 played a role in the complementation by human cells of the defect of CT3, we constructed a series of mouse cell lines expressing human HSP70 and tested them for their ability to localize CT3 $\mathrm{T}$ antigen in the nucleus and for their ability to be transformed by CT3 DNA. Mouse cell lines expressing human HSP70 protein were able to translocate mutant CT3 $T$ antigen into the nucleus and were transformed by CT3 at rates comparable with wild-type SV40. Mouse-inducible HSP70 protein was not able to translocate cytoplasmic $T$ antigen in Swiss 3T3 mouse fibroblast cells, even after heat shock. Apparently human HSP70 is capable of complementing directly or indirectly the structural and functional alterations in SV40 $\mathrm{T}$ antigen introduced by the CT3 mutation.

[Key Words: CT3 cytoplasmic mutant; SV40 T antigen; Swiss 3T3 mouse cells; HSP70 protein]

Received August 6, 1991; revised version accepted September 23, 1991.

The phosphoprotein SV40 T antigen is normally transported to the nucleus by a short nuclear localization signal sequence composed of basic amino acids (Kalderon et al. 1984a,b; Colledge et al. 1986; Dingwall and Laskey 1986; Burglin and DeRobertis 1987), similar to that of other nuclear proteins (Dingwall and Laskey 1986; Wychowski et al. 1986; Burglin and DeRobertis 1987; Picard and Yamamoto 1987; Dang and Lee 1989; Roux et al. 1990). Components in the nuclear pore complex are thought to accomplish nuclear localization in two steps: rapid binding at the nuclear envelope, followed by slow transport through the nuclear pore (Richardson et al. 1988; Borer et al. 1989).

The relationship between localization and function has been reported for many oncogene products (Van Etten et al. 1989). In fully transformed cells, SV40 T antigen is uniquely localized both to the nucleus and to the outer cell surface (Santos and Butel 1985). In rat liver, SV40 $\mathrm{T}$ antigen transport to the nucleus is mediated by an ATP-dependent active transport system (Markland et al. 1987). Microinjection of antibodies raised against negatively charged peptides (Asp-Asp-Glu-Asp) inhibits nuclear transport of SV40 T antigen in a variety of cell lines
(Yoneda et al. 1988), suggesting that the cellular molecules involved in nuclear transport can be modulated experimentally. Deletion or mutation of the region of the $\mathrm{T}$-antigen gene encoding the nuclear localization signal damages the capacity of mouse, hamster, and monkey cells to transport $\mathrm{T}$ antigen to the nucleus (Lanford and Butel 1982, 1984; Kalderon et al. 1984a,b; Alfano and McMacken 1989). For instance, the localization-signal mutant $\mathrm{T}$ antigen encoded by SV40 CT3, in which asparagine substitutes for lysine at amino acid 128, remains entirely in the cytoplasm of mouse cells (Lanford and Butel 1980, 1982, 1984).

Unlike the cells of mice, human precrisis fibroblast cells can be transformed efficiently by CT3 T antigen. Translocation of cytoplasmic $\mathrm{T}$ antigen into the nucleus in human precrisis fibroblast cells occurs with high efficiency as well (Chen et al. 1988). We have hypothesized that factors present in human fibroblasts function in a species-specific manner to complement the defect of CT3 $\mathrm{T}$ antigen, assisting transport of the antigen to the nucleus of human fibroblast cells, where CT3 T antigen can then bring about transformation (Chen et al. 1988).

The human heat shock multigene family encodes a set 
of different proteins from genes located on at least three human chromosomes: 6, 14, and 21 (Harrison et al. 1987). The amino acid sequences of heat shock proteins are well conserved among different species (Hunt and Morimoto 1985). Their localization is cell cycle regulated; they are cytoplasmic in the absence of heat shock but accumulate in the nucleus in the $S$ phase of the cell cycle (Milarski and Morimoto 1986; Milarski et al. 1989). The major constitutive human heat shock protein is encoded by a gene on chromosome 6 , close to the major histocompatibility complex (MHC) (Harrison et al. 1987; Sargent et al. 1989). Human major HSP70 protein, as with other heat shock proteins, has a nuclear localization signal sequence and has been reported to be translocated into the nucleus upon heat shock (Welch and Feramisco 1984; Arrigo et al. 1988). Heat shock proteins have been reported to interact with oncogene products (Koskinen et al. 1991). In ras/p53-transformed rat fibroblast cells, the constitutive heat shock cognate protein hsc70 can complex with mutant p53 protein (Pinhasi-Kimhi et al. 1986; Finlay et al. 1988), whereas adenovirus ElA protein, which has been reported to increase transcription of human HSP7O genes (Wu et al. 1986; Banerii et al. 1987), has been found colocalized with HSP70 protein in the nucleus (White et al. 1988). Variant-sized versions of SV40 $\mathrm{T}$ antigen have been reported to bind to heat shock proteins (Sawai and Butel 1989; May et al. 1991). In transformed mouse cells the complex formed between variant SV40 $\mathrm{T}$ antigen and cellular HSP70 does not require that any additional complex be formed between variant SV40 T antigen and cellular p53 protein (Sawai and Butel 1989). The mechanistic role, if any, of HSP70-variant T-antigen complex has not been elucidated.

We have isolated stable transfectants of Swiss 3T3 mouse fibroblast cells that express human major HSP70 protein constitutively under normal culture conditions. With these cell lines we have been able to show that this member of the human HSP70 heat shock protein family can complement the translocation defect of CT3 T antigen in Swiss 3T3 mouse fibroblast cells, thereby permitting mouse fibroblast cells to be transformed by the mutant viral protein at frequency comparable with wildtype SV40 $\mathrm{T}$ antigen. Heat shock studies showed that this effect is species specific, as inducible mouse HSP70 protein was not able to complement the nuclear localization defect of SV40 CT3 mutation.

\section{Results}

Translocation of CT3 $T$ antigen into the nucleus in human fibroblast cells is due to human species-specific factors

CT3 $\mathrm{T}$ antigen is translocated into the nucleus as well as into the cytoplasm in human precrisis fibroblast cells, whereas it stays in the cytoplasm in Swiss $3 \mathrm{~T} 3$ mouse fibroblast cells (Lanford and Butel 1984; Chen et al. 1988). To determine which human chromosomes encode the information for this species-specific difference, we assayed localization of CT3 T antigen in a panel of six different human-mouse hybrid cell lines. Direct transformation of these hybrids was not possible owing to their partially transformed phenotypes; therefore, we transfected the hybrid lines with neo ${ }^{x}$ plasmids containing the gene for either CT3 or wild-type SV40 T antigen and selected neo ${ }^{\mathrm{r}}$ subclones. Neo ${ }^{\mathrm{r}}$ clones were subjected to Southern blot hybridization to check the integration of viral DNA sequences. All neor clones had integrated either CT3 or wild-type T antigen genes into many different sites (data not shown). Indirect immunofluorescence staining with monoclonal anti-T-antigen antibody (Pab416) was used to check the localization of either СT3 or wild-type $\mathrm{T}$ antigen in these clones.

Two human-mouse hybrid cell lines translocated CT3 $\mathrm{T}$ antigen into the nucleus as well as into the cytoplasm, and four did not (Table 1; Figure $1 \mathrm{~A}-\mathrm{F}$ ). This result demonstrates that one, or a small number, of human gene products is capable of complementing at least a portion of the CT3 defect. Localization of CT3 T antigen and wild-type $T$ antigen did not change with extensive subcloning of transformed hybrid lines. As expected, wildtype SV40 T antigen was localized into the nucleus exclusively in all six different hybrid cell lines (data not shown). We observed that chromosome 6 is the only human chromosome shared by the two hybrids that translocated CT3 T antigen to the nucleus. As shown by Harrison et al. (1987), the multiple copies of human heat shock protein gene on chromosome 6 exhibit a substantial amount of basal expression in the absence of heat shock. However, human chromosome 6 is also present in hybrid BDXE364a, which did not translocate CT3 T antigen.

Because no single human chromosome provided a complete correlation with CT3 translocation, we checked the presence of HSP70-specific sequences in the six hybrid cell lines by Southern hybridization using a 2.3-kb HindIII-BamHI fragment of plasmid Rous sarcoma virus (pRSV)-HSP70 gene as a probe. The two hybrid cell lines that translocated CT3 $\mathrm{T}$ antigen to the nucleus generated bands at the position of HSP70-specific sequences in human HeLa cells, as well as bands of mouse HSP70 sequences (Fig. 2). The three hybrid cell lines WAVR4dA19, BDA17b17-1, and BDA14b25, which did not translocate CT3 $\mathrm{T}$ antigen into the nucleus, did not contain any detectable human HSP70 sequences. Hybrid cell line BDXE364a, which also does not translocate CT3 $\mathrm{T}$ antigen into the nucleus, showed gross genomic rearrangement of human HSP70 sequences (Fig. 2). These data are consistent with the hypothesis that constitutively expressing major human heat shock protein from chromosome 6 of the human genome is capable of at least partial restoration of the defect in nuclear transport of CT3 $\mathrm{T}$ antigen.

Human major HSP70 protein is expressed stably in subclones of Swiss $3 T 3$ mouse fibroblast cells

To test directly the hypothesis that human HSP70 protein is one of the proteins capable of translocating CT3 T 
Table 1. Localization of CT3 $T$ antigen in human-mouse hybrid cell lines carrying subsets of human chromosomes

\begin{tabular}{|c|c|c|c|c|c|c|}
\hline & WAV4RdA19 & $41 \mathrm{Pt} 2 \mathrm{a}$ & $\mathrm{BDA} 10 \mathrm{a} 3$ & BDA17b17-1 & BDA14b25 & BDXE364a \\
\hline CT3 $\mathrm{T}$ antigen & cyto & nuc & nuc & cyto & cyto & cyto \\
\hline human $H S P 70$ & - & + & + & - & - & rearranged \\
\hline & \multicolumn{6}{|c|}{ human chromosomes present } \\
\hline 1 & - & - & - & + & + & - \\
\hline 2 & - & - & + & - & - & + \\
\hline 3 & - & + & - & - & - & - \\
\hline 4 & - & - & - & + & + & - \\
\hline 5 & - & - & - & + & - & - \\
\hline $6\left({ }^{*}\right)$ & - & + & + & - & - & + \\
\hline 7 & - & - & - & - & + & - \\
\hline 8 & - & - & + & + & - & - \\
\hline 9 & - & - & - & - & - & + \\
\hline 10 & - & - & + & - & - & - \\
\hline 11 & - & - & + & - & - & - \\
\hline 12 & - & - & + & + & - & - \\
\hline 13 & - & - & + & + & - & - \\
\hline 14 & - & + & - & - & + & + \\
\hline 15 & - & + & - & - & - & - \\
\hline 16 & - & - & + & + & - & - \\
\hline 17 & - & - & + & - & - & - \\
\hline 18 & - & - & - & - & - & - \\
\hline 19 & - & + & - & - & - & - \\
\hline 20 & - & - & + & - & - & - \\
\hline 21 & + & - & - & + & - & + \\
\hline 22 & + & + & - & + & - & - \\
\hline $\mathrm{X}$ & - & - & + & + & + & - \\
\hline
\end{tabular}

The localization of CT3 T antigen, determined by immunofluorescence with monoclonal antibody, was not changed upon extensive subcloning of transformed hybrid lines. (cyto) All cells had $\mathrm{T}$ antigen only in their cytoplasm; (nuc) a fraction $(\sim 50 \%)$ of cells had $\mathrm{T}$ antigen in their nuclei, as well as in their cytoplasm (see Fig. 1). The presence of human HSP7O genes was determined by Southern blot analysis of the hybrid clones. Synteny (*) indicates that human chromosome 6 carries factors for translocation of CT3 T antigen to the nucleus of a mouse cell.

antigen to the nucleus of mouse cells, DNA encoding human major heat shock protein HSP70 was transfected into Swiss 3T3 mouse fibroblast cells together with the gene for neomycin resistance. To assure a high level of expression, the human HSP70 gene was placed under the control of the RSV long terminal repeat (LTR) promoter. Two to three weeks after transfection, neo ${ }^{\mathrm{r}}$ clones were picked randomly and expanded in medium selective for those clones. The stable integration of transfected human major HSP70 DNA in neo ${ }^{r}$ cells was checked by DNA hybridization with a $2.3-\mathrm{kb}$ HindIII-BamHI fragment of human major HSP70 sequences as probe. The probe detected four bands of homologous, endogenous mouse HSP70 DNA in untransfected as well as transfected $3 \mathrm{~T} 3$ mouse cells, and additional different size inserts of exogenous human HSP70 DNA in transfected cells (data not shown). We chose to study further five HSP70-positive clones.

The expression of human major HSP70 protein in clones carrying human major HSP70 DNA was determined by immunoblotting cell extracts with mouse $\mathrm{mAb} 3 \mathrm{a} 3$ directed against human HSP70 protein (gift of Dr. R.I. Morimoto). Three of five clones carrying human major $\mathrm{HSP} 70$ sequences $(\mathrm{H} 1, \mathrm{H} 2$, and $\mathrm{H} 5)$ showed detectable levels of exogenous human major HSP70 protein in addition to a mouse hsc 70 protein constitutively present in Swiss 3T3 mouse fibroblast cells (Fig. 3A). Against this endogenous background, the antibody recognized a slightly faster-migrating human major HSP70 protein in control HeLa cells and in the three positive transfected
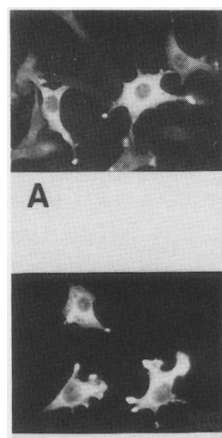

D
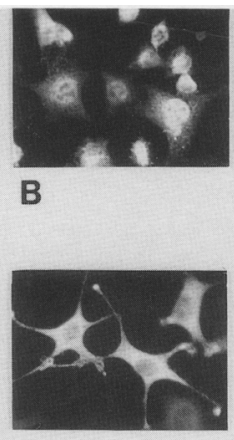

E

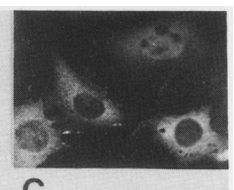

C

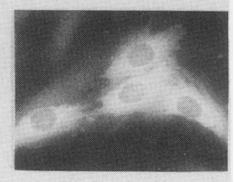

$F$
Figure 1. Immunofluorescence staining of SV40 T antigen in hybrid cell lines transfected by CT3 SV40 T antigen. Hybrid cells were stained with monoclonal antibody to SV40 T antigen. (A) Hybrid WAVR4dA19; (B) hybrid 4lpt2a; $(C)$ hybrid BDA10a3; $(D)$ hybrid BDA17b17-1; $(E)$ hybrid BDA14b25; $(F)$ hybrid BDXE364a. All hybrid lines showed CT3 in the cytoplasm. In addition, nuclear localization of CT3 T antigen was seen in cells of hybrid lines $41 \mathrm{pt} 2 \mathrm{a}$ and BDA10a3. 


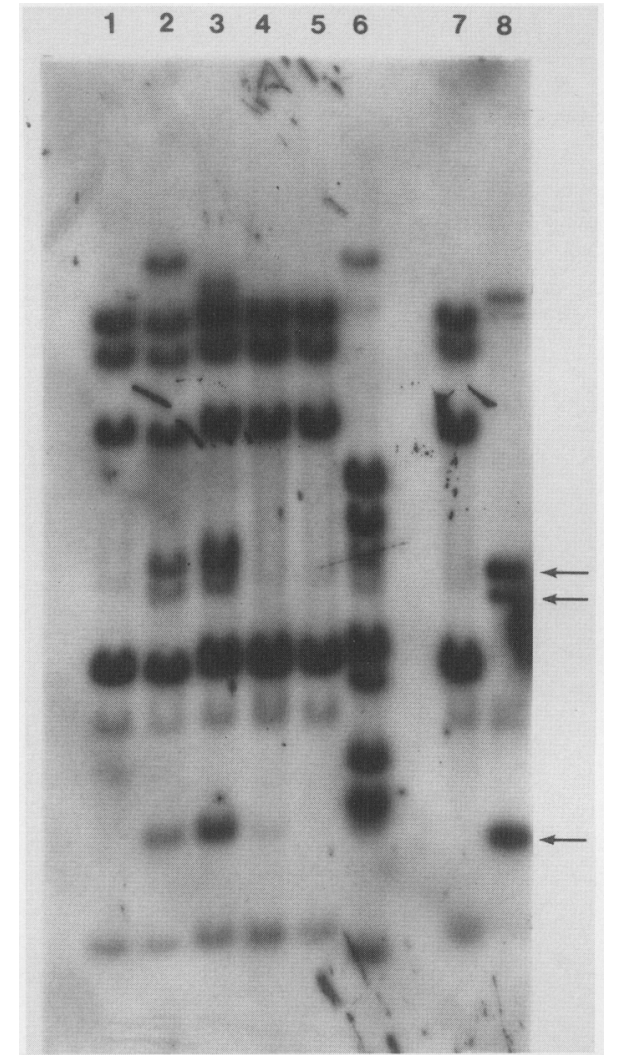

Figure 2. Presence of human HSP70 DNA in hybrid cell lines that can translocate CT3 $\mathrm{T}$ antigen into the nucleus. Southern blot hybridization of human HSP70 gene in human-mouse hybrid cell lines. Genomic DNAs of six hybrid cell lines were prepared, cut with PstI, and hybridized with a $2.3-\mathrm{kb}$ HindIIIBamHI fragment of pRSV-HSP70 plasmid. (Lanes 1-6) DNAs from WAVR4dA19, 4lpt2a, BDAl0a3, BDA17bl7-1, BDA14b25, and BDXE364a, respectively. Note the presence of additional bands, presumably human heat shock protein sequences, in $41 \mathrm{Pt} 2 \mathrm{a}$ and BDA10a3 cell lines. In hybrid BDXE364a, human HSP70 sequences are rearranged and assumed to be inactive. Human and mouse species control DNAs were from mouse $3 \mathrm{~T} 3$ cells (lane 7) and human HeLa cells (lane 81.

clones (Fig. 3A). The same antibody was used for immunofluorescence on coverslips of H1 or H5 (Fig. 3B). Untransfected 3T3 cells show only background fluorescence with this antibody. Constitutive, exogenous human HSP70 appears in $\mathrm{Hl}$ as a bright, completely cytoplasmic antigen (Fig. 3B). The cytoplasmic localization of exogenous human HSP70 in $\mathrm{Hl}$ cells did not change after subcloning and a second drug selection with hygromycin.

The expression of human major HSP70 protein had no detectable effect on the growth control of cell lines $\mathrm{Hl}$ and $\mathrm{H} 5$ (Table 2). Growth responses in both $10 \%$ and $1 \%$ FCS and in agarose were comparable for $\mathrm{H1}, \mathrm{H} 5$, and control 3T3 mouse cells. In particular, neither control Swiss $3 \mathrm{~T} 3$ nor clones $\mathrm{Hl}$ and $\mathrm{H} 5$ were able to grow in semisolid medium. Control Swiss 3T3 mouse fibroblast cells and clones $\mathrm{H} 1$ and $\mathrm{H} 5$ also did not show appreciable differences in actin organization under normal cell culture conditions (Table 2). Subclones of $\mathrm{Hl}$ and $\mathrm{H} 5$ transfected with hygromycin-resistance plasmid and selected for secondary resistance to this drug did not differ from $\mathrm{Hl}$ or $\mathrm{H} 5$ in growth properties (Table 2).

\section{Mouse cell lines $H 1$ and $H 5$ can be transformed by SV4O cytoplasmic mutant $T$ antigen CT3 at high efficiency}

The cytoplasmic localization mutant CT3 $\mathrm{T}$ antigen transforms Swiss 3T3 mouse cells, but at a very low frequency compared with wild-type $\mathrm{T}$ antigen (Lanford and Butel 1984). In contrast, CT3 can transform human fibroblasts with the same high efficiency as wild-type $\mathrm{T}$ antigen (Chen et al. 1988). To demonstrate directly the capacity of human major HSP70 protein to restore function while complementing the nuclear localization defect of CT3 T antigen, we assayed the appearance of foci with transformed morphology in $1 \%$ serum after CT3 transfection of clones $\mathrm{H} 1$ and $\mathrm{H} 5$ with a plasmid carrying the gene for SV40 mutant T antigen CT3. Confirming earlier reports (Lanford and Butel 1984; Chen et al. 1988), we found the transformation frequency of CT3 in control mouse fibroblast cells to be very low compared with that of wild-type $\mathrm{T}$ antigen (Table 3). In contrast, CT3 was able to transform clones $\mathrm{Hl}$ and $\mathrm{H} 5$ with an efficiency similar to that of wild-type SV40 (Table 3). We conclude that in the presence of human HSP70 protein CT3 T antigen has reacquired the capacity to transform mouse cells stably at high efficiency.

Subclones of $\mathrm{H} 1$ were isolated directly as dense foci after transfection with either CT3 or wild-type T-antigen gene. Such clones were found to be transformed stably, by the criteria of increased growth rate in regular and low serum, increased anchorage independence, and decreased actin cytoskeletal organization (Table 2). We also isolated and characterized a rare CT3-transfected 3T3 clone. Such clones arise with a frequency $\sim 1 \%$ of that obtained with wild-type $T$ antigen (Table 3). These cells have partially lost growth control but are not fully transformed (Table 2). We conclude that CT3 can transform $\mathrm{H} 1$ and $\mathrm{H} 5$ mouse cells completely at high efficiency.

To determine whether CT3 could generate transformed subclones of $\mathrm{H} 1$ or $\mathrm{H} 5$ in the absence of direct selection for the transformed phenotype, we introduced $\mathrm{T}$ antigen into the neo ${ }^{\mathrm{r}}$ clones $\mathrm{H} 1$ and $\mathrm{H} 5$ without requiring it to act as a transforming agent, by using hygromycin as a second selective drug. Two to three weeks after cotransfection of hygromycin-resistance gene with either the CT3 $\mathrm{T}$ antigen or the wild-type $\mathrm{T}$-antigen gene, we isolated hygromycin-resistant clones H1-CT3hyg, H5-CT3-hyg, H1-WT-hyg, and H5-WT-hyg. These clones were all more transformed than WT-3T3 and as transformed as H1-CT3 or H5-CT3 (Table 2), suggesting that the selectively isolated complete transformants $\mathrm{H} 1-\mathrm{CT} 3$ and $\mathrm{H} 5-\mathrm{CT} 3$ were not products of rare events requiring selection.

Human major HSP70 protein is still produced in $\mathrm{H1}$ subclones transformed by either wild-type or CT3 $\mathrm{T}$ an- 

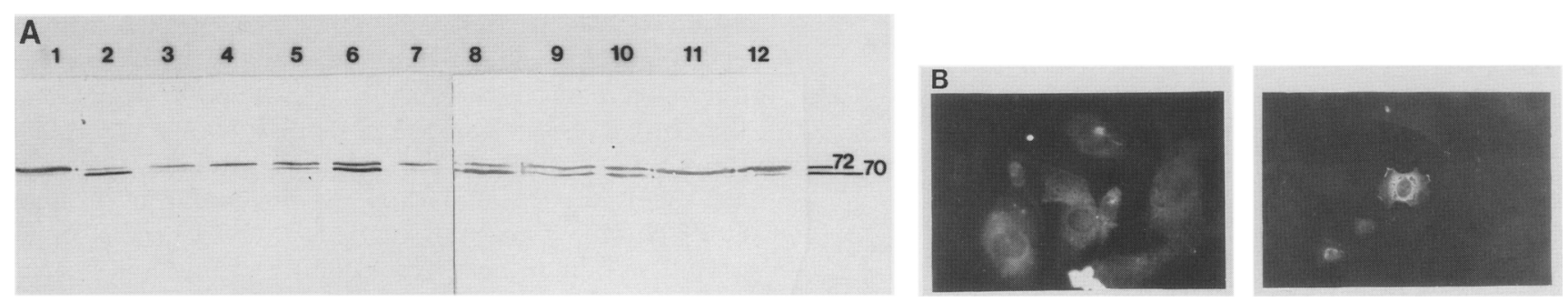

Figure 3. Human HSP70 protein expression in Swiss 3T3 clones carrying integrated human HSP70 gene. $(A)$ Western blot of cell lysates from HSP70 DNA positive clones, reacted with mouse anti-human HSP70 mAb 3a3. (Lane 1) Control 3T3 cells, showing mouse hsc70 as a slow-migrating band. Mouse HSP70 does not appear unless cells are heat shocked. (Lanes 2-6) Human heat shock protein 3T3 lines H5, H4, H3, H2, and H1, respectively. (Lane 7) 3T3-neo control cells. (Lane 8) A 1 : 1 mixture of extracts from H5 and HeLa cells, showing coincidence of HeLa and H5 human fast bands. (Lane 9) A $1: 1$ mixture of extracts from HeLa and 3T3 cells. (Lane 10) H5 extract. (Lane 11) 3T3 extract. (Lane 12) HeLa extract. The slower-migrating human band is a 72-kD member of the heat shock protein family, which is constitutively expressed in HeLa cells (Milarski and Morimoto 1986). We conclude that the fast band in clones $\mathrm{H} 1, \mathrm{H} 2$, and $\mathrm{H} 5$ that is not seen in untransfected mouse cells is exogenous human major HSP70 protein. (B) Immunofluorescence assay with $\mathrm{mAb} 3 \mathrm{a} 3$ showing background fluorescence with no detectable mouse antigen in 3T3 cells (left), and cytoplasmic human HSP70 in subline $\mathrm{Hl}$ (right).

Table 2. Growth control of $3 T 3$ and sublines expressing human HSP7O protein

\begin{tabular}{|c|c|c|c|c|c|}
\hline \multirow{2}{*}{$\begin{array}{l}\text { Mouse cell } \\
\text { line }\end{array}$} & \multicolumn{2}{|c|}{$\begin{array}{l}\text { Saturation density } \\
\left(\text { cells/dish } \times 10^{-4}\right)\end{array}$} & \multirow{2}{*}{$\begin{array}{l}\text { Anchorage- } \\
\text { independent } \\
\text { colonies }\end{array}$} & \multirow{2}{*}{$\begin{array}{l}\text { Doubling } \\
\text { time in } 10 \% \\
\text { serum }(\mathrm{hr})\end{array}$} & \multirow{2}{*}{$\begin{array}{l}\text { Actin } \\
\text { cables }\end{array}$} \\
\hline & $10 \%$ serum & $1 \%$ serum & & & \\
\hline \multicolumn{6}{|l|}{ Normal } \\
\hline 3T3-neo & 79 & no growth & - & 22.9 & $+++t$ \\
\hline $\mathrm{H} 1$ & 72 & no growth & - & 20.9 & ++++ \\
\hline H5 & 69 & no growth & - & 23.9 & ++++ \\
\hline H1-hyg & 80 & no growth & - & 20.6 & ND \\
\hline H5-hyg & 72.5 & no growth & - & 22.8 & ND \\
\hline \multicolumn{6}{|l|}{ Transformed } \\
\hline 3T3-WT & 208 & 122 & ++ & 13.5 & - \\
\hline 3Т3-СT3 & 190 & 23.5 & + & 17 & ++ \\
\hline H1-WT & 254 & 199 & +++ & 16 & - \\
\hline $\mathrm{H} 1-\mathrm{CT} 3$ & 251 & 71 & +++ & 16 & - \\
\hline Hl-CT3-hyg & 230 & 57 & +++ & 16 & - \\
\hline H5-CT3-hyg & 199 & 73 & $++t$ & 16.2 & - \\
\hline H1-WT-hyg & 200 & 114 & ND & ND & - \\
\hline H5-WT-hyg & 204 & 135 & ND & ND & - \\
\hline
\end{tabular}

Neomycin-resistant 3T3 and descendent cell lines were assayed for growth control and cytoskeletal actin organization. H1, $\mathrm{H} 5$, and their hygromycin-resistant subclones did not lose any detectable degree of growth control as a result of expressing exogenous human HSP70 protein. Cell growth assays are described in Materials and methods.

tigen (Fig. 4). No genomic rearrangement of human major HSP70 gene was detected by Southern blot in these subclones (data not shown). We conclude that the human HSP70 protein synthesized by a transfected gene in clones $\mathrm{H} 1$ and $\mathrm{H} 5$ enables these mouse cells to translocate continuously CT3 cytoplasmic mutant T antigen into their nuclei and thereby to give rise to transformed clones after transfection.

Mutant CT3 $T$ antigen and human HSP70 protein are both found in the nuclei of H1-CT3- and H5-CT3-transformed cells

Because we had found that mAb $3 a 3$ gave only back-
Table 3. Transformation frequencies of wild-type and CT3 T-antigen genes in Swiss $3 T 3$ mouse fibroblast cells and in sublines $\mathrm{H} 1$ and $\mathrm{H} 5$

\begin{tabular}{lclc}
\hline $\begin{array}{c}\text { Cell } \\
\text { line }\end{array}$ & $\begin{array}{c}\text { Human } \\
\text { HSP70 }\end{array}$ & $\begin{array}{c}\text { SV40 T } \\
\text { antigen } \\
\text { gene }\end{array}$ & $\begin{array}{c}\text { Transformation } \\
\text { frequency } \\
\text { (dense foci/10 } \\
\text { infected cells) }\end{array}$ \\
\hline 3T3 & - & CT3 & $0.25 \pm 0.4$ \\
H1 & - & wild type & $20 \pm 7$ \\
& + & CT3 & $16 \pm 5$ \\
\hline
\end{tabular}

Transformation was assayed as dense foci appearing per $10^{5}$ transfected cells, after 3 weeks in $1 \%$ serum. 


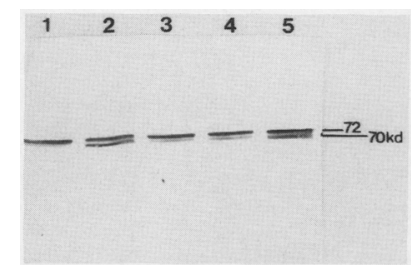

Figure 4. Immunoblot of human HSP70 protein in H1-CT3 and H1-WT cells. (Lane 1) Control neo ${ }^{\mathrm{r}} 3 \mathrm{~T} 3$ cells; (lanes 2-4) $\mathrm{H} 1$ subclones transformed by CT3 mutant T antigen; (lane 5) $\mathrm{Hl}$ subclone transformed by wild-type $\mathrm{T}$ antigen. Human HSP70 is present in all transformed subclones of $\mathrm{H} 1$.

ground fluorescence in 3T3 cells or their transformants (Fig. 3B), we used this antibody to localize specifically human $\mathrm{HSP} 70$ in $\mathrm{Hl}$ and $\mathrm{H} 5$, and their wild-type- and CT3-transformed subclones. The localization of $T$ antigen in transformed lines was assayed on sister coverslips. Figure 5 shows the results of these assays for $\mathrm{Hl}$ and its subclones. 3T3 cells transformed by either wild-type or CT3 $\mathrm{T}$ antigen showed only nonspecific background fluorescence (Fig. 5C,D) and localized their $T$ antigens to the nucleus and cytoplasm (Fig. 5A,B). H1-wild-typetransformed cells localized $\mathrm{T}$ antigen to the nucleus and human HSP70 to the cytoplasm, as expected in the absence of any interaction (Fig. 5E,G). H1-CT3-transformed cells, however, localized both CT3 $\mathrm{T}$ antigen and human HSP70 to the nuclei of some cells (Fig. 5F,H). H5 and its CT3 subclones gave similar results.

Four of five H1-wild-type-transformed clones behaved as in Figure 5, E and G; seven of eight CT3-transformed $\mathrm{Hl}$ or $\mathrm{H} 5$ subclones showed human HSP70 in the nucleus as well as in the cytoplasm, and all eight showed CT3 T antigen in the nucleus as well as in the cytoplasm (Table 4). These data are consistent with a specific inter- action between $\mathrm{CT} 3$ mutant $\mathrm{T}$ antigen and human HSP70 proteins in mouse cells, either directly or through unknown mediating molecules. This hypothesis predicts that human skin fibroblasts (HSFs), which are transformed by CT3 $\mathrm{T}$ antigen with high efficiency (Chen et al. 1988), should also show a movement of human HSP70 from cytoplasm to nucleus after CT3 transformation. The human heat shock family of proteins visualized by mAb $3 \mathrm{a} 3$ in human cells was distributed evenly throughout HSFs transformed either by CT3 or wild-type $\mathrm{T}$ antigen, a result consistent with the hypothesis but otherwise uninformative (Table 4).

\section{Interaction besween exogenous human HSP70 protein and $T$ antigen in $3 T 3$ mouse cells}

Variant molecular weight versions of SV40 T antigen bind to mammalian HSP70 proteins, including mouse hsc70 protein (Sawai and Butel 1989; May et al. 1991). We used immunoprecipitation with monoclonal mouse anti- $\mathrm{T}$ antigen (Pab108) and monoclonal mouse anti-human-HSP70 antibody (C92F3A5) to search for specific complex formation between human HSP70 and CT3 T antigen in mouse cells. Although C92F3A5 detects inducible mouse HSP70, as well as constitutive human HSP70, it does not detect constitutive mouse hsc70 or any other heat shock proteins in an uninduced mouse cell. Although we detected coprecipitation of mouse p53 with antibody to $\mathrm{T}$ antigen, we failed to detect coprecipitation of either CT3 or wild-type SV40 T antigen or mouse p53 protein in immunoprecipitates by using C92F3A5 antibody to HSP70 (data not shown). We conclude that complex formation between human HSP70 and CT3 T antigen, if any, cannot be as stable as the complex formation between $\mathrm{T}$ antigen and $\mathrm{p} 53$.

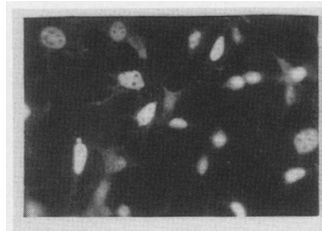

A

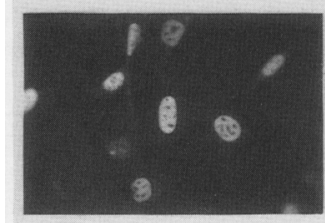

E

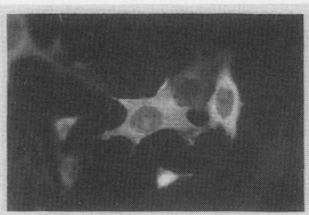

B

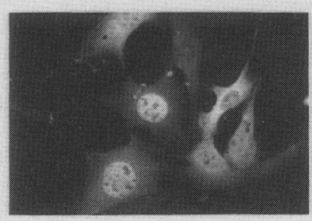

$\mathbf{F}$

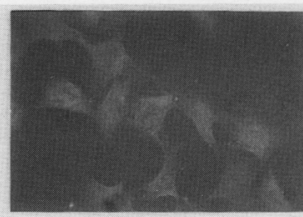

C

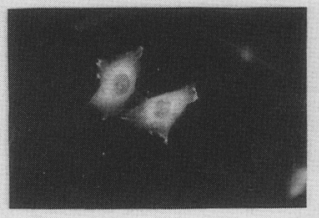

G

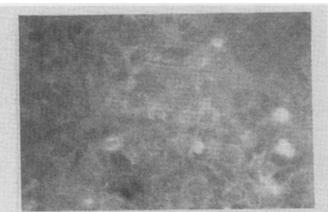

D

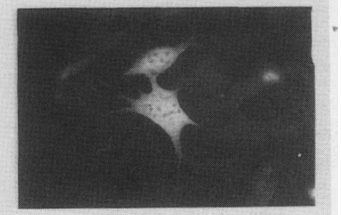

H

Figure 5. Human HSP70 and CT3 T antigen both localize in the nucleus of $\mathrm{H} 1$ mouse cells. Immunofluorescent detection of $\mathrm{T}$ antigen $(A, B, E, F)$ and human HSP70 $(C, D, G, H)$ in $3 \mathrm{~T} 3$ and $\mathrm{H} 1$ cells transformed by SV40 wild-type or CT3 T antigen. $(A) \mathrm{Nuclear} \mathrm{T}$ antigen in 3T3-WT-transformed cells. $(B)$ Cytoplasmic T antigen in 3T3-CT3-partially transformed cells. [C (3T3-WT) and D (3T3CT3)] Background, nonspecific fluorescence in these cells. $(E)$ Nuclear T antigen in H1-WT-transformed cells. $(F)$ Nuclear as well as cytoplasmic T antigen in H1-CT3 cells. $(G)$ Cytoplasmic human HSP70 in H1-WT-transformed cells. $(H)$ Nuclear as well as cytoplasmic human HSP70 in H1-CT3-transformed cells. 
Table 4. Localization of SV4O T antigen and HSP7O in mouse and human cell lines

\begin{tabular}{lcccccc}
\hline & & \multicolumn{2}{c}{ T antigen } & \multicolumn{2}{c}{ HSP70 } \\
\cline { 7 - 8 } \cline { 5 - 6 } Cell line & Subclones & nuc & cyto & nuc & cyto \\
\hline Mouse lines & & & & & & \\
3T3-neo & 1 & - & - & - & - \\
3T3-CT3 & 1 & - & + & - & - \\
3T3-WT & 1 & + & - & - & - \\
H1 & 1 & - & - & - & + \\
H5 & 1 & - & - & - & + \\
H1-hyg & 1 & - & - & - & + \\
H5-hyg & 1 & - & - & - & + \\
H1-CT3 & 1 & + & + & + & + \\
H5-CT3 & 1 & + & + & - & + \\
H1-CT3-hyg & 2 & + & + & + & - \\
H5-CT3-hyg & 4 & + & + & + & + \\
H1-WT-hyg & 1 & + & - & + & - \\
H5-WT-hyg & 2 & + & - & - & + \\
H1-WT & 1 & + & - & - & + \\
H5-WT & 1 & + & - & - & + \\
Human lines & & & & & & \\
human skin & 1 & - & - & - & - \\
fibroblast & & & & & & \\
HeLa & 1 & - & - & + & + \\
HSF-CT3 & 2 & + & + & + & + \\
HSF-WT & 2 & + & - & + & + \\
\hline
\end{tabular}

Cells were grown on coverslips and stained with antibody to either human HSP70 or SV40 T antigen. Localization was determined by inspection at $500 \times$. (nuc + , cyto -) Antigen was seen in the nuclei of cells examined and not seen in the cytoplasm; (nuc - , cyto + ) antigen was seen in the cytoplasm of cells examined and not in their nuclei (nuc + cyto + ) antigen was seen in the cytoplasm of $\geqslant 10 \%$ of cells examined and also in the nuclei of $\geqslant 10 \%$ of cells examined. Typically, HSP70transfected, CT3-transformed cell lines contained nuclear $\mathrm{T}$ antigen in $\geqslant 50 \%$ of cells.

\section{Mouse-inducible heat shock protein does not} complement CT3 mutant $T$ antigen

Human HSP70 is constitutively produced at $37^{\circ} \mathrm{C}$ by $\mathrm{Hl}$ and $\mathrm{H} 5$ cells and by the human tumor line HeLa (Table 4). Mouse cells subject to heat shock at $42^{\circ} \mathrm{C}$ will produce elevated levels of mouse-inducible HSP70 protein (Fig. 6A). We reasoned that if the interaction between
CT3 T antigen and human HSP70 was not species specific, the excess of mouse HSP70 produced after heat shock might be able to complement the localization of CT3 T antigen in 3T3-CT3 cells. We found, however, that inducible mouse HSP70 protein does not have the capacity to complement the nuclear localization defect of CT3 T antigen (Fig. 6B). CT3-transformed 3T3 mouse cells were incubated at $42^{\circ} \mathrm{C}$ for 2,4 , or $6 \mathrm{hr}$ and then shifted to $37^{\circ} \mathrm{C}$ to allow them to accumulate mouse-inducible HSP70 protein. Cell lysates were prepared at each time point and subjected to immunoblot analysis for mouse-inducible HSP70 protein. After $2 \mathrm{hr}$ at $42^{\circ} \mathrm{C}$ mouse-inducible HSP70 protein was increased. The level of constitutively expressed mouse heat shock cognate protein remained the same for $\leqslant 6 \mathrm{hr}$ (Fig. 6A). The localization of CT3 $\mathrm{T}$ antigen in heat-shocked 3T3 mouse fibroblast cells was assayed on coverslips from duplicate plates by indirect immunofluorescence staining with mouse monoclonal anti-T-antigen PAb416. CT3 T antigen was not transported to the nucleus in heat-shocked mouse cells, despite the increase in mouse HSP70 protein (Fig. 6B). Heat shock does not interfere with the translocation of CT3 $\mathrm{T}$ antigen localization to the nucleus in H1-CT3 or H5-CT3 cells (data not shown). This suggests that induced mouse HSP70 does not synergistically interact with transfected human HSP70 protein in these cells.

We conclude that mouse-inducible HSP70 protein, unlike human major HSP70 protein, does not have the ability to translocate SV40 CT3 T antigen to the nucleus, even after induction by heat shock, and that the interaction of human HSP70 with CT3 T antigen is specific.

\section{Discussion}

In human cells the family of heat shock proteins includes both constitutive and inducible genes located on at least three different human chromosomes-6, 14, and 21 (Harrison et al. 1987). Their cellular localization is regulated in part by the cell cycle (Milarski and Morimoto 1986; Milarski et al. 1989). The family of human HSP70 proteins has a variety of functions, including supporting protein folding and assembly (Ostermann et al.
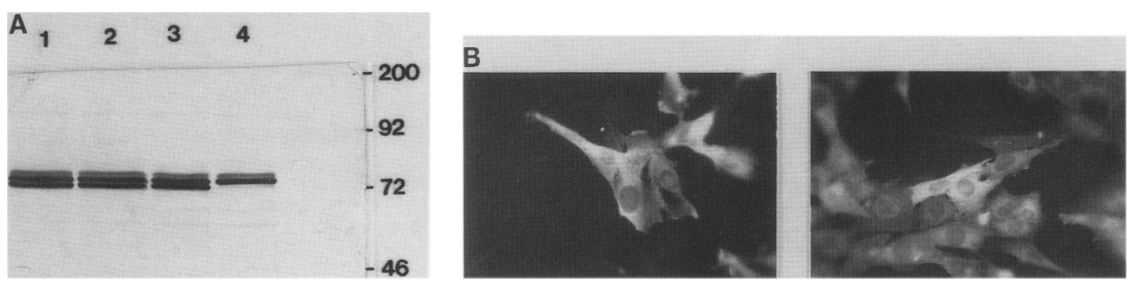

Figure 6. Mouse HSP70 proteins induced by heat shock do not complement the localization or functional defect of CT3 T antigen. (A) Western blot of HSP70 induced by heat shock in 3T3-CT3 mouse cells and detected by $\mathrm{mAb} 3 \mathrm{a} 3$. The lowest of three immunoreactive bands is the mouse-inducible HSP70 protein. The middle band is the constitutively expressed mouse hsc70 protein. The top band is not identified but is present in mouse cells at both temperatures. (Lane 1) $6 \mathrm{hr}$ at $42^{\circ} \mathrm{C}$, followed by $6 \mathrm{hr}$ at $37^{\circ} \mathrm{C}$; (lane 2) $4 \mathrm{hr}$ at $42^{\circ} \mathrm{C}$, followed by $4 \mathrm{hr}$ at $37^{\circ} \mathrm{C}$; (lane 3$) 2 \mathrm{hr}$ at $42^{\circ} \mathrm{C}$, followed by $2 \mathrm{hr}$ at $37^{\circ} \mathrm{C}$, (lane 4 ) no heat shock. Two hours of heat shock is sufficient to generate a maximal production of mouse-inducible HSP70. $(B)$ Cytoplasmic localization of CT3 T antigen in 3T3-CT3 mouse cells after heat shock. Cells were grown on coverslips, fixed, and stained with monoclonal mouse-anti-SV40-T antigen. (Left) CT3 T antigen in the cytoplasm under normal culture conditions at $37^{\circ} \mathrm{C}$; (right) CT3 $\mathrm{T}$ antigen remains in the cytoplasm after $2 \mathrm{hr}$ of heat shock at $42^{\circ} \mathrm{C}$. 
1989; Parsell and Sauer 1989; Beckman et al. 1990), assisting in translocation of secretory and precursor proteins (Chirico et al. 1988; Deshaies et al. 1988), DNA replication (Alfano and McMacken 1989), uncoating of clathrin vesicles (Chappel et al. 1986), recovery of nucleolar morphology after heat shock (Pelham 1984; Welch and Suhan 1985), and modulation of developmental pathway (Kothary et al. 1987). We have shown that human-specific factors located on human chromosome 6 are capable of complementing the nuclear localization and the function of the CT3 cytoplasmic localization mutant of SV40 T antigen. We have also shown that the human major HSP70 protein located on chromosome 6 is sufficient to restore completely CT3 to normal function in mouse 3T3 cells, both translocating CT3 into the nucleus of mouse fibroblast cells and restoring it to functionality as a transforming protein. Although Hwang and Kaguni (1991) have shown that the bacterial heat shock protein dnaK can complement $d n a A^{-}$mutants, we have found the first example of a human heat shock protein complementing an amino acid substitution mutation in another protein, restoring its localization and function.

CT3-transformed cell lines H1-CT3 and H5-CT3, which translocated CT3 $\mathrm{T}$ antigen into the nucleus, showed typical increased growth rate in low serum and capacity to grow in the absence of anchorage. Because of the high frequency of transformation by $\mathrm{CT} 3$ of $\mathrm{Hl}$ and H5 cells, and because H1-CT3 and H5-CT3 subclones all remained stable mixtures of cells expressing $T$ antigen in the cytoplasm as well as the nucleus rather than evolving toward populations with $\mathrm{T}$ antigen only in their nuclei, we consider it unlikely that CT3 $\mathrm{T}$ antigen reverted to wild type in these cells.

The effect of human HSP70 on CT3 translocation in mouse cells is species specific. We were able to induce mouse HSP70 protein synthesis by heat shock of 3T3CT3 cells. CT3 T antigen remained entirely cytoplasmic in these cells, despite the presence of induced mouse HSP70. It is not clear how human major HSP70 protein translocates CT3 $\mathrm{T}$ antigen into the nucleus. It remains to be seen whether the change in localization of human HSP70 protein and restoration of transforming activity in $\mathrm{Hl}$ and $\mathrm{H} 5$ cells are the results of continuous molecular interaction between CT3 $\mathrm{T}$ antigen and human HSP70 protein, or whether complexes such as p53-CT3 $\mathrm{T}$ antigen play a necessary role in CT3-human HSP70 interaction.

Antibodies against negatively charged polypeptides block the transport of SV40 T antigen into the nucleus in various cells, including mouse fibroblasts (Yoneda et al. 1988). This suggests that wild-type SV40 T antigen may be transported to the nucleus by a charge-sensitive receptor molecule that recognizes a nuclear signal sequence on the T-antigen molecule. We are currently testing the hypothesis that CT3 $\mathrm{T}$ antigen is not properly recognized by these receptor molecules in mouse cells and that human major HSP70 protein can somehow modify CT3 $\mathrm{T}$ antigen so that its mutant signal sequence is recognized and the molecule is thereby transported to the nucleus by mouse nuclear localization molecules, perhaps while it is still complexed with other mouse proteins.

Human HSP70 and CT3 T antigen might have a sufficient interaction short of stable binding to allow cryptic nuclear localization signals to be detected by mouse transport proteins. In this context it is useful to consider that HSP70 might suppress a number of conformationrelated mutant phenotypes (Hwang and Kaguni 1991).

\section{Materials and methods}

Cells and antibodies

Swiss 3T3 mouse fibroblast cells were grown in Dulbecco's modified Eagle medium (DMEM) supplemented with 10\% FCS. Drug-selected cell lines were grown in either $10 \%$ FCS/G418 $(300 \mu \mathrm{g} / \mathrm{ml})$ or $10 \% \mathrm{FCS} /$ hygromycin $(75 \mu \mathrm{g} / \mathrm{ml})$ medium. Mouse anti-human HSP70 mAB $3 \mathrm{a} 3$ was kindly provided by Dr. Richard Morimoto. This antibody recognizes the HSP70 family of proteins, including the heat shock cognate proteins of human and mouse cells. A $1: 20$ dilution of $\mathrm{mAb} 3 \mathrm{a} 3$ was used in both immunoblot and immunofluorescence staining for the presence of HSP70 proteins. Another antibody with somewhat more restricted specificity, C92F3A5, was kindly provided by Dr. William Welch. C92F3A5 recognizes inducible mouse HSP70 protein and human HSP70 protein but not mouse hsc70 cognate protein. This antibody was used at $1: 250$ dilution in $1 \%$ BSA solution.

\section{Southern blot hybridization}

Fifteen micrograms of genomic DNAs was prepared from neo ${ }^{r}$ clones and was digested by restriction enzymes $(4 \mathrm{U} / \mu \mathrm{g})$ overnight at $37^{\circ} \mathrm{C}$. Restricted genomic DNAs were then electrophoresed through an $0.8 \%$ agarose gel and transferred onto nylon membrane. Southern hybridization was done under high-stringency conditions. The hybridization solution contains $50 \%$ deionized formamide, $10 \%$ dextran sulfate, $1 \%$ SDS, and $1 \mathrm{M}$ $\mathrm{NaCl}$. After hybridization overnight at $42^{\circ} \mathrm{C}$, the filter was washed successively by $2 \times$ SSC; $2 \times$ SSC, $1 \%$ SDS, $0.1 \times$ SSC. The filter was then exposed on Kodak XAR-5 film with an intensifying screen at $-80^{\circ} \mathrm{C}$.

\section{Western blot analysis}

Cells $\left(2 \times 10^{6}\right)$ were washed twice with ice-cold PBS buffer harvested at $4^{\circ} \mathrm{C}$, and centrifuged at $240 \mathrm{~g}$ for $10 \mathrm{~min}$. NP-40 lysis buffer [ $20 \mathrm{mM}$ Tris ( $\mathrm{pH} 8.3$ ) buffer, $145 \mathrm{~mm} \mathrm{NaCl}, 1 \%$ NP-40, 0.1 mM PMSF, $10 \mathrm{~mm}$ DTT] was added to cell pellets, and the mixture was incubated on ice for $30 \mathrm{~min}$. After incubation, extracellular materials were removed by centrifugation at $35,000 \mathrm{~g}$ for $40 \mathrm{~min}$. Loading buffer was added to the supernatant, and this was boiled for $5 \mathrm{~min}$ and centrifuged at $17,360 \mathrm{~g}$ for $10 \mathrm{~min}$ and immediately loaded for $15 \%$ SDS-PAGE overnight at $50 \mathrm{~V}$.

Electrophoresed proteins were transferred onto nitrocellulose membrane on a semidry gel transfer system. After $2-3 \mathrm{hr}$ transfer at room temperature, membrane with transferred proteins was treated with blocking solution [ $2 \%$ nonfat, dried milk (wt/ vol), $0.2 \%$ Tween $20(\mathrm{vol} / \mathrm{vol})]$ for $1 \mathrm{hr}$ at room temperature and washed for $20 \mathrm{~min}$ with TBS buffer. Mouse anti-human HSP70 $\mathrm{mAb} 3 \mathrm{a} 3$ was then added to the membrane at a ratio of $1: 20$ in blocking solution. Reaction was continued for $2 \mathrm{hr}$ at room temperature, and the membrane was washed with TBS for 20 min at room temperature. Alkaline phosphatase-conjugated goat anti-mouse IgG $(1: 3,000$ dilution in blocking buffer) was 
added to the membrane, and reaction continued for $\mathrm{l} \mathrm{hr}$ at room temperature. After reaction, membrane was washed with TBS for $20 \mathrm{~min}$ and placed in developing solution $[50 \mathrm{mg} / \mathrm{ml}$ of NBT in $70 \%$ (vol/vol) dimethyl formamide, $50 \mathrm{mg} / \mathrm{ml}$ of bromochloroindolyl phosphate (BCIP) in $100 \%$ dimethyl formamide] to visualize antigenic HSP70 protein.

\section{Immunofluorescence staining}

The day before staining, cells were plated out at a density of $2 \times 10^{5}$ cells $/ 35-\mathrm{mm}$ plate. The next day, cells were fixed by a $3.7 \%$ formaldehyde ( $\mathrm{vol} / \mathrm{vol}$ ) solution for $20 \mathrm{~min}$ at room temperature and washed with $1 \times$ PBS several times; $1 \%$ (vol/vol) NP-40 was then added to permeabilize cell membrane for 10 min. Monoclonal antibody to human HSP70 or to SV40 T antigen was added for $1 \mathrm{hr}$ in a humidified incubator at $37^{\circ} \mathrm{C}$. Coverslips were then washed with PBS several times, and FITCconjugated anti-mouse second antibody $(1: 100$ or $1: 200$ dilution/ was added for $1 \mathrm{hr}$. Coverslips were washed, mounted, and stored at $4^{\circ} \mathrm{C}$ until examination. Stained samples were photographed on Kodak Tri-X film with a Zeiss immunofluorescence microscope with fluorochrome specific filters.

\section{Cell growth assays}

Growth assays were carried out by conventional methods (Brown et al. 1986; Chen et al. 1988). Cells were plated out at $5 \times 10^{4}$ cells $/ 35-\mathrm{mm}$ plate. Dishes were trypsinized and cells were counted every 2 days for 10 days by using the trypan blue exclusion method to count only viable cells. For the anchorageindependence assay, either $5 \times 10^{4}$ or $5 \times 10^{5}$ cells in medium containing $10 \%$ FCS, $1 \times$ Dulbecco's modified Eagle medium (DMEM), and $0.33 \%$ Seaplaque agarose were plated out onto $60-\mathrm{mm}$ plates that contained a bed of $2 \mathrm{ml}$ of $10 \%$ FCS, $1 \times$ DME, and $0.5 \%$ Seaplaque agarose. Cells were fed once a week with soft agar. After 2-3 weeks, colonies were scored with the assistance of a dissecting microscope. Scoring was as follows: (-) no detectable colonies of 50 cells or more; $|+| 1-10$ small colonies per plate; $(++\mid 10-100$ colonies per plate, some of them larger than 50 cells; and $(+++)>100$ colonies per plate, many large colonies.

\section{DNA transfection}

Each DNA was mixed with $125 \mathrm{mM} \mathrm{CaCl}{ }^{2}, 1 \times \mathrm{BBS}$ buffer $[25$ mM $N, N$-bis (2-hydroxyethyl)-2-aminoethane sulfonate (BES) at $\mathrm{pH} 6.95,140 \mathrm{mM} \mathrm{NaCl}, 0.75 \mathrm{~mm} \mathrm{Na} \mathrm{HPO}_{4}$ ] while bubbling gently, and incubated at room temperature for 30-45 min. Transfection solutions were added drop-wise to cell plates and were incubated overnight in a humidified incubator $137^{\circ} \mathrm{C}$, $\left.3-5 \% \mathrm{CO}_{2}\right)$. After $12-16 \mathrm{hr}$ of transfection, medium was removed and cells were fed with fresh medium. Two to three days after transfection, cells were split in a ratio of $1: 3$ and placed in selection medium $(300 \mu \mathrm{g} / \mathrm{ml}$ of G418 or $75 \mu \mathrm{g} / \mathrm{ml}$ of hygromycin).

\section{Immunoprecipitation}

Cell monolayers at $80 \%$ of confluency were washed several times with methionine-free DMEM, fed with the same medium, and incubated for $30 \mathrm{~min}$ at $37^{\circ} \mathrm{C}$ in a humidified incubator. The medium was removed, and cells were refed with methionine-free DMEM supplemented with $2 \%$ dialyzed FCS containing $150 \mu \mathrm{Ci}$ of ${ }^{35} \mathrm{~S}$. After $4 \mathrm{hr}$ of incubation in a humidified incubator, cell lysates were prepared from each plate in RIPA buffer [150 mM NaCl, $10 \mathrm{~mm}$ Tris- $\mathrm{HCl}(\mathrm{pH} 7.4), 1 \%$ deox- ycholate, 1\% Triton X-100, 0.1\% SDS], and antibody-either C92F3A5 or PAb108-was added to the cell lysates. After $2 \mathrm{hr}$ of reaction at $4^{\circ} \mathrm{C}$, immune complexes were precipitated by reaction with protein $\mathrm{A}$ solution and centrifugation. Immunoprecipitates were suspended in RIPA buffer, centrifuged three times, boiled for $5 \mathrm{~min}$, and resolved by $15 \%$ SDS-PAGE. The PAGE gel was treated with $\mathrm{En}^{3} \mathrm{Hance}$ (New England Nuclear) and autoradiographed at $-80^{\circ} \mathrm{C}$ on Kodak XAR-5 film.

\section{Acknowledgments}

We thank Zhenlan Liu, Pei Lan Lee, and Yi-Horng Lee for technical support, Dr. Frank Ruddle for hybrid cells, Dr. William Welch for antibody, and Dr. Richard Morimoto for antibodies and advice. This work was supported by grants from the $\mathrm{Na}$ tional Cancer Institute and the American Cancer Society.

The publication costs of this article were defrayed in part by payment of page charges. This article must therefore be hereby marked "advertisement" in accordance with 18 USC section 1734 solely to indicate this fact.

\section{References}

Alfano, C. and R. McMacken. 1989. Heat shock protein mediated disassembly of nucleoprotein structure is required for initiation of bacteriophage DNA replication. I. Biol. Chem. 264: 10709-10718.

Arrigo, A.P., J.P. Suhan, and W.J. Welch. 1988. Dynamic changes in the structure and intracellular localization of the mammalian low molecular weight heat shock protein. Mol. Cell. Biol. 8: 5059-5071.

Banerii, S., K. Lang, and R.I. Morimoto. 1987. Erythroid lineagespecific expression and inducibility of the major heat shock protein HSP70 during avian embryogenesis. Genes \& Dev. 1: 946-953.

Beckman, R.P., L.A. Mizzen, and W.J. Welch. 1990. Interaction of HSP70 with newly synthesized proteins: Implications for protein folding and assembly. Science 248: 850-854.

Borer, R., C.F. Lehner, H.M. Eppenberger, and E.A. Nigg. 1989. Major nucleolar proteins shuttle between nucleus and cytoplasm. Cell 56: 379-390.

Brown, A.M., R.S. Wildin, T.J. Prendergast, and H.E. Varmus. 1986. A retrovirus vector expressing the putative mammary oncogene int- 1 causes partial transformation of a mammary epithelial cell line. Cell 46: 1001-1009.

Burglin, T.R., and E.M. DeRobertis. 1987. The nuclear migration signal of Xenopus laevis nucleoplasmin. EMBO $\%$ 6: $2617-2625$.

Chappel, T.G., W.J. Welch, D.M. Schlossman, D.B. Palter, M.J. Schlesinger, and J.E. Rothman. 1986. Uncoating ATPase is a member of the 70Kd family of stress protein. Cell 45: 3-13.

Chen, S., P. Levesque, E. Pomert, and R.E. Pollack. 1988. Transformation of precrisis human cells by the simian virus 40 cytoplasmic localization mutant PSVCT3 is accompanied by nuclear T antigen. J. Virol. 61: 3521-3527.

Chirico, W.J., M.G. Waters, and G.Blobel. 1988. 70Kd heat shock mediated proteins stimulate protein translocation into microsomes. Nature 332: 805-810.

Colledge, W.H., W.D. Richardson, M.D. Edge, and A.E. Smith. 1986. Extensive mutagenesis of the nuclear location signal of simian virus 40 Large-T antigen. Mol.Cell.Biol. 6: 41364139.

Dang, C.V., and W.M.F. Lee. 1989. Nuclear localization targeting sequences of c-erbA, c-myb, N-myc, P53 HSP70 and HIV tat proteins. I. Biol.Chem. 264: 18019-18023. 
Deshaies, R.J., B.D. Koch, M. Wer-Washburne, E.A. Craig, and R. Schekman. 1988. A superfamily of stress proteins facilitates translocation of secretory and mitochondrial precursor polypeptides. Nature 332: 800-805.

Dingwall, C. and R.A. Laskey. 1986. Protein import into the cell nucleus. Annu. Rev. Cell. Biol. 2: 367-390.

Finlay, C.A., P.W. Hinds, T.H. Tan, D. Eliyahu, M. Oren, and A.J. Levine. 1988. Activating mutations for transformation by $\mathrm{p} 53$ produce a gene product that forms a hsc70-p 53 complex with an altered half-life. Mol. Cell. Biol. 8: 531-539.

Harrison, G.S., H.A. Drabkin, F.T. Kao, J. Hartz, I.M. Hart, E.H.Y. Chu, B.J. Wu, and R.I. Morimoto. 1987. Chromosomal location of human genes encoding major heat shock protein HSP70. Somatic Cell. Genet. 13: 119-130.

Hunt. C. and R.I. Morimoto. 1985. Conserved features of eukaryotic HSP70 genes revealed by comparison with the nucleotide sequence of human HSP70. Proc. Natl. Acad. Sci. 82: 6455-6459.

Hwang, D.S. and J.M. Kaguni. 1991. dna K protein stimulates a mutant form of dna A protein in Escherichia coli DNA replication. I. Biol. Chem. 266: 7537-7541.

Kalderon, D., W.D. Richardson, A.F. Markham, and A.E. Smith. 1984a. Sequence requirements for nuclear localization of SV40 Large T antigen. Nature 311: 33-38.

Kalderon, D., B.L. Roberts, W.D. Richardson, and A.E. Smith. 1984b. A short amino acid sequence able to specify nuclear location. Cell 39: 479-509.

Koskinen, P.J., G. Sistonen, R.I. Evan, R.I. Morimoto, and K. Alitalo. 1991. Nuclear colocalization of cellular and viral myc proteins with HSP70 in myc-expressing cells. J. Virol. 65: 842-851.

Kothary, R., M.D. Perry, L.A. Moran, and J. Rossant. 1987. Cell lineage specific expression of the mouse HSP68 during embryogenesis. Dev. Biol. 121: 342-348.

Lanford, R.E. and J.S. Butel. 1980. Biochemical characterization of nuclear and cytoplasmic forms of SV40 tumor antigens encoded by parental and transport-defective mutant SV40adenovirus7 hybrid viruses. Virology 105: 314-327.

- 1982. Intracellular transport of SV40 large tumor antigen: A mutation which abolishes migration to the nucleus does not prevent association with the cell surface. Virology 119: 169-184.

1984. Construction and characterization of an SV40 mutant defective in nuclear transport of $\mathrm{T}$ antigen. Cell 37: 801-813.

Markland, W., A.E. Smith, and B.L. Roberts. 1987. Signal-dependent translocation of simian virus 40 large $T$ antigen into rat liver nuclei in a cell-free system. Mol. Cell. Biol. 7: 42554265.

May, E., C. Breugnot, A. Duthu, and P. May. 1991. Immunological evidence for the association between simian virus 40 $115 \mathrm{kd}$ super $\mathrm{T}$ antigen and HSP70 proteins in rat, monkey, and human cells. Virology 180: 285-293.

Milarski, K.L. and R.I. Morimoto. 1986. Expression of human HSP70 during the synthetic phase of the cell cycle. Proc. Natl. Acad. Sci. 83: 9517-9521.

Milarski, K.L., W.J. Welch, and R.I. Morimoto. 1989. Cell cycledependent association of HSP70 with specific cellular proteins. J. Cell. Biol. 108: 413-423.

Ostermann, J., A.L. Horwich, W. Neupert, and F.U. Hart. 1989. Protein folding in mitochondria requires complex formation with HSP60 and ATP hydrolysis. Nature 341: 125-130.

Parsell, O.A. and R.T. Sauer. 1989. Induction of a heat shocklike response by unfolded protein in E. coli: Dependence on protein level not on protein degradation. Genes \& Dev. 3: $1226-1232$.
Pelham, H.R.B. 1984. HSP70 protein accelerates the recovery of nucleolar morphology after heat shock. EMBO I. 3: 30953100 .

Picard, D. and K.R. Yamamoto. 1987. Two signals mediate hormone dependent nuclear localization of the glucocorticoid receptor. $E M B O$ I. 6: 3333-3340.

Pinhasi-Kimhi, O., D. Michalovitz, A. Ben-Zeev, and M.Oren. 1986. Specific interaction between the p53 cellular tumor antigen and major heat shock proteins. Nature 320: 182184.

Richardson, W.D., A.D. Mills., S.M. Dilworth, R.A. Laskey, and C. Dingwall. 1988. Nuclear protein migration involves two steps: Rapid binding at the nuclear envelope followed by slower translocation through nuclear pores. Cell 52: 655664.

Roux, P., J.M. Blanchard, A. Fernandez, N. Lamb, P. Jeanteu, and M. Piechaczyk. 1990. Nuclear localization of c-fos,but not v-fos proteins is controlled by extracellular signal. Cell 63: $341-351$.

Santos, M. and J.S. Butel. 1985. Surface T antigen expression in simian virus 40 transformed mouse cells; correlation with cell growth rate. Mol. Cell. Biol. 5: 1051-1057.

Sargent, C.A., I. Dunhan, J. Trowsdale, and R.D. Campbell. 1989. Human major histocompatability complex contains the genes for major heat shock protein HSP70. Proc. Natl. Acad. Sci. 86: 1968-1972.

Sawai, E. and J.S. Butel. 1989. Association of cellular heat shock protein with simian virus 40 large $T$ antigen in transformed cells. J. virol. 63: 3961-3973.

Van Etten, R.A., P. Jackson, and D. Baltimore. 1989. The mouse type IV C-abl gene product is a nuclear protein and activation of transforming ability is associated with cytoplasmic localization. Cell 58: 669-678.

Welch, W.J. and J.R. Feramisco. 1984. Nuclear and nucleolar localization of the 72,000 dalton heat shock protein in heatshocked mammalian cells. . Biol. Chem. 259: 4501-4513.

Welch, W.J. and J.P. Suhan. 1985. Morphological study of the mammalian stress response: Characterization of changes in cytoplasmic organelles, cytoskeleton and nucleoli, and appearance of intracellular actin filaments in rat fibroblast cells. J. Cell. Biol. 101: 1198-1211.

White, E., D. Spector, and W.J. Welch. 1988. Differential distribution of the adenovirus ElA proteins and colocalization of E1A with the 70-kilodalton heat shock protein in infected cells. J. Virol. 62: 4153-4166.

Wu, B.J., H.C. Hurst, N.C. Jones, and R.I. Morimoto. 1986 The E1A 13S product of Adenovirus 5 activates transcription of the cellular human HSP70 gene. Mol. Cell. Biol. 6: 2994 2997.

Wychowski, C., D. Benichou, and M. Girard. 1986. A domain of SV40 capsid polypeptide VPI that specifies migration into the cell nucleus. EMBO I. 5: 2569-2576.

Yoneda,Y., N. Imamoto-Sonobe, Y. Matsuoka, R. Iwamoto, Y. Kiho, and T. Uchida. 1988. Antibodies to Asp-Asp-Glu-Asp can inhibit transport of nuclear proteins into the nucleus. Science 242: 275-278. 


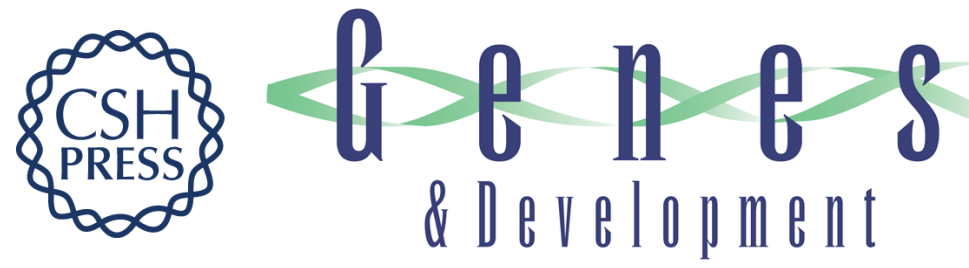

\section{Human major HSP70 protein complements the localization and functional defects of cytoplasmic mutant SV40 T antigen in Swiss 3T3 mouse fibroblast cells.}

D I Jeoung, S Chen, J Windsor, et al.

Genes Dev. 1991, 5:

Access the most recent version at doi:10.1101/gad.5.12a.2235

References This article cites 46 articles, 22 of which can be accessed free at:

http://genesdev.cshlp.org/content/5/12a/2235.full.html\#ref-list-1

License

Email Alerting Receive free email alerts when new articles cite this article - sign up in the box at the top Service right corner of the article or click here.

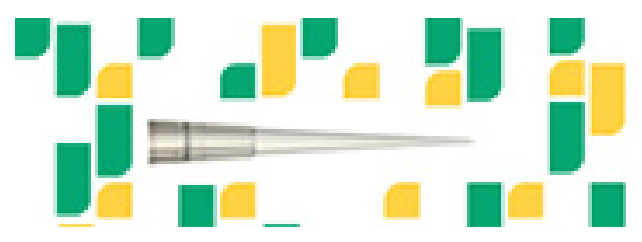

Focused on your science. 